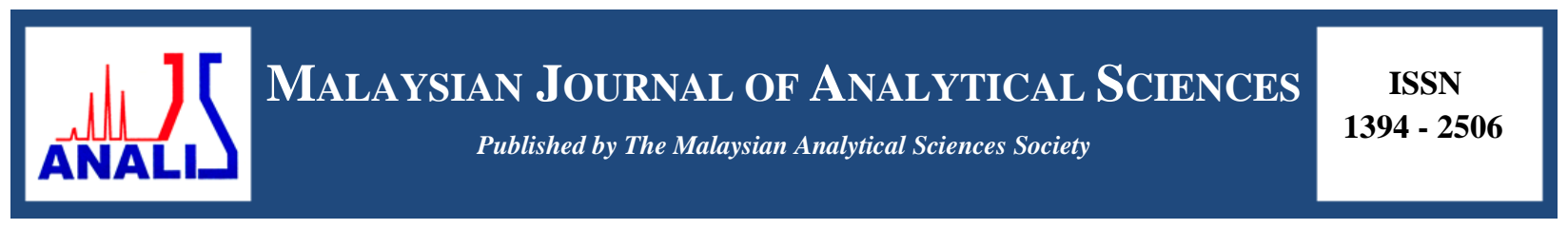

\title{
CHARACTERIZATION OF $\mathrm{CaCO}_{3}$ MICROSPHERES FABRICATED USING DISTILLED WATER
}

\author{
(Pencirian $\mathrm{CaCO}_{3}$ Mikrosfera Difabrikasi Menggunakan Air Suling) \\ Intan Nabila Sabri ${ }^{1}$, Nadiawati Alias $^{2}$, Abdul Manaf $\mathrm{Ali}^{2}$, Javeed Shaikh Mohammed ${ }^{1}$ * \\ ${ }^{\text {I}}$ Faculty of Innovative Design and Technology, \\ Universiti Sultan Zainal Abidin, Gong Badak Campus, 21300 Kuala Terengganu, Terengganu, Malaysia \\ ${ }^{2}$ Faculty of Bioresources and Food Industry, \\ Universiti Sultan Zainal Abidin, Besut Campus, 22200 Tembila, Terengganu, Malaysia \\ *Corresponding author: javeedsm@unisza.edu.my
}

Received: 14 April 2015; Accepted: 30 November 2015

\begin{abstract}
Calcium carbonate $\left(\mathrm{CaCO}_{3}\right)$ microspheres ( $\mu$-spheres) are widely used as inorganic templates (or cores) for fabricating nanoengineered microcapsules. Deionized water is commonly used in the fabrication of $\mathrm{CaCO}_{3} \mu$-spheres using precipitation reaction between calcium chloride $\left(\mathrm{CaCl}_{2}\right)$ and sodium carbonate $\left(\mathrm{Na}_{2} \mathrm{CO}_{3}\right)$ solutions under vigorous stirring. However, in the current work distilled water was used throughout the experiments. Furthermore, two simple fabrication approaches, namely membrane filtration and centrifugation approaches, were used in order to understand the effect of different experimental factors on the size and shape of $\mathrm{CaCO}_{3} \mu$-spheres. For the membrane filtration approach, the experimental factors tested included mixing procedure of solutions, stirring speeds, drying techniques, and types of filter paper used. For the centrifugation approach, the experimental factors tested included mixing procedure of solutions, stirring speeds, centrifugation times, drying techniques, and quantity of washing agents used. The size measurements and shape of the $\mathrm{CaCO}_{3} \mu$-spheres were investigated using compound microscopy. Scanning electron microscopy (SEM) was used to observe the fine surface morphological details of the $\mathrm{CaCO}_{3} \mu$-spheres. Overall results indicate that the centrifugation approach can yield better $\mathrm{CaCO}_{3} \mu$-spheres as compared to the membrane filtration approach in terms of narrow size distribution and uniform spherical shape. The fabricated $\mathrm{CaCO}_{3} \mu$-spheres can be used as inorganic templates for fabricating nano-engineered microcapsules.
\end{abstract}

Keywords: $\mathrm{CaCO}_{3}$ microspheres, scanning electron microscopy (SEM), compound microscopy

\begin{abstract}
Abstrak
Kalsium karbonat $\left(\mathrm{CaCO}_{3}\right)$ mikrosfera ( $\mu$-sfera) digunakan secara meluas sebagai templat bukan organik (atau teras) untuk memfabrikasi mikrokapsul nano-kejuruteraan. Air ternyahion lazim digunakan dalam fabrikasi $\mathrm{CaCO}_{3} \mu$-sfera dengan menggunakan tindak balas pemendakan antara larutan kalsium klorida $\left(\mathrm{CaCl}_{2}\right)$ dan natrium karbonat $\left(\mathrm{Na}_{2} \mathrm{CO}_{3}\right)$ dengan pengacauan yang laju. Namun begitu, dalam kerja-kerja semasa air suling telah digunakan sepanjang eksperimen. Dua teknik fabrikasi yang ringkas, iaitu teknik penapisan membran dan pengemparan telah digunakan untuk memahami kesan faktor eksperimen yang berbeza terhadap saiz dan bentuk $\mathrm{CaCO}_{3} \mu$-sfera. Bagi teknik penapisan membran, faktor - faktor eksperimen yang diuji termasuk prosedur pencampuran larutan, kelajuan pengacauan, teknik pengeringan, dan jenis kertas penapis yang digunakan. Bagi teknik pegemparan, faktor - faktor eksperimen yang diuji pula termasuk prosedur pencampuran larutan, kelajuan pengacauan, masa pengemparan, teknik pengeringan, dan kuantiti agen pembasuhan yang digunakan. Ukuran saiz dan bentuk $\mathrm{CaCO}_{3} \mu$-sfera telah dikaji dengan menggunakan mikroskopi sebatian. Mikroskopi elektron pengimbasan (SEM) digunakan untuk meneliti morfologi permukaan halus $\mathrm{CaCO}_{3} \mu$-sfera. Keputusan kajian menunjukkan bahawa teknik pengemparan mampu menghasilkan $\mathrm{CaCO}_{3} \mu$-sfera lebih baik berbanding teknik penapisan membran dari segi taburan saiz yang kecil dan berbentuk sfera yang seragam. Rekaan $\mathrm{CaCO}_{3} \mu$-sfera boleh digunakan sebagai templat bukan organik untuk fabrikasi mikrokapsul nano-kejuruteraan.
\end{abstract}


Kata kunci: $\mathrm{CaCO}_{3}$ microsfera, mikroskop elektron pengimbasan (SEM), mikroskopi sebatian

\section{Introduction}

Calcium carbonate $\left(\mathrm{CaCO}_{3}\right)$ microspheres ( $\mu$-spheres) have been extensively used as core templates to fabricate nano-engineered microcapsules for drug delivery applications $[1,2] . \mathrm{CaCO}_{3}$ cores can be easily fabricated and can also be easily dissolved by using ethylenediaminetetraacetic acid (EDTA) after the layer-by-layer (LbL) multilayer self-assembly process [3]. Several different approaches have been used to fabricate $\mathrm{CaCO}_{3} \mu$-spheres or coprecipitated protein- $\mathrm{CaCO}_{3} \mu$-spheres in the $\mathrm{nm}-\mu \mathrm{m}$ size range $[1,4-10]$. The membrane filtration and centrifugation approaches are two simple and low-cost approaches for fabricating $\mathrm{CaCO}_{3} \mu$-spheres. The membrane filtration approach is based on pressure-driven separation of microspheres from the solution [11]. A vacuum pump can aid in applying pressure (lower than the atmospheric pressure) to the filtration equipment for faster separation. The centrifugation approach is based on centrifugal force-driven sedimentation of microspheres in the solution [12].

Deionized water (with resistivity of $18 \mathrm{M} \Omega \cdot \mathrm{cm}$ ) is commonly used in the fabrication of $\mathrm{CaCO}_{3} \mu$-spheres using precipitation reaction between calcium chloride $\left(\mathrm{CaCl}_{2}\right)$ and sodium carbonate $\left(\mathrm{Na}_{2} \mathrm{CO}_{3}\right)$ solutions under vigorous stirring. However, in the current work distilled water was used throughout the experiments. Furthermore, the easyto-use membrane filtration and centrifugation approaches were tested in the current work in order to achieve uniformly-shaped $\mathrm{CaCO}_{3} \mu$-spheres with narrow size distribution. Mixing procedure of solutions, stirring speeds, drying techniques, types of filter paper, and centrifugation times are some of the experimental factors that need to be evaluated for their potential to influence the formation of uniformly-shaped and monodispersed $\mathrm{CaCO}_{3} \mu$-spheres [13-15]. Limited details are available in literature regarding the influence of mixing procedure of solutions, stirring speeds, drying techniques, types of filter paper, and centrifugation times on the formation of uniformly-shaped and monodispersed $\mathrm{CaCO}_{3} \mu$-spheres using distilled water. Therefore, the aim of the current work was to gain further knowledge about the influence of experimental factors in preparing uniformly-shaped $\mathrm{CaCO}_{3} \mu$-spheres with narrow size distribution. The knowledge gained from the current work can be used to prepare $\mathrm{CaCO}_{3}$ microtemplates using distilled water for the fabrication of nano-engineered microcapsules.

\section{Chemicals}

\section{Materials and Methods}

Calcium chloride $\left(\mathrm{CaCl}_{2}\right)$ (Fisher Scientific UK Ltd., Loughborough, UK), Sodium carbonate $\left(\mathrm{Na}_{2} \mathrm{CO}_{3}\right)(\mathrm{Nacalai}$ Tesque Inc., Kyoto, Japan) and acetone (RCI Labscan Ltd., Bangkok, Thailand) were purchased and used.

\section{Fabrication of $\mathrm{CaCO}_{3} \mu$-spheres}

Two different fabrication approaches, namely membrane filtration and centrifugation approaches, were used in order to prepare uniformly-shaped $\mathrm{CaCO}_{3} \mu$-spheres with a narrow size distribution. In both approaches, precipitation reaction between $\mathrm{CaCl}_{2}$ and $\mathrm{Na}_{2} \mathrm{CO}_{3}$ solutions was used. The experiments were carried out at room temperature unless specified otherwise.

\section{Membrane filtration approach}

The $\mathrm{CaCO}_{3} \mu$-spheres were fabricated by precipitation reaction between $\mathrm{CaCl}_{2}$ and $\mathrm{Na}_{2} \mathrm{CO}_{3}$ solutions as reported by Petrov et al. [1] with slight modification. Briefly, $20 \mathrm{~mL}$ of $0.33 \mathrm{M}$ solutions of $\mathrm{CaCl}_{2}$ and $\mathrm{Na}_{2} \mathrm{CO}_{3}$ were mixed under vigorous stirring at $900 \mathrm{rpm}$ for $30 \mathrm{~s}$ at room temperature. After the stirrer was stopped, the reaction mixture was left without stirring for $10 \mathrm{~min}$. Subsequently, the precipitated $\mathrm{CaCO}_{3} \mu$-spheres were collected and thoroughly washed with $100 \mathrm{~mL}$ of distilled water three times followed by acetone one time using membrane filtration system equipped with a filter paper. Finally, the $\mu$-spheres were dried.

Two different mixing procedures, four different stirring speeds, two different drying techniques, and two types of filter paper were carried out in order to understand the effect of these experimental factors on the morphology and size distribution of $\mathrm{CaCO}_{3} \mu$-spheres. The two mixing procedures of solutions used were: $\mathrm{Na}_{2} \mathrm{CO}_{3}$ solution was added rapidly (directly) to $\mathrm{CaCl}_{2}$ solution and $\mathrm{Na}_{2} \mathrm{CO}_{3}$ solution was added drop-by-drop (one drop per second) to $\mathrm{CaCl}_{2}$ solution. The four stirring speeds of magnetic stirrer used were: $300 \mathrm{rpm}, 600 \mathrm{rpm}, 900 \mathrm{rpm}$, and $1200 \mathrm{rpm}$ 
for $30 \mathrm{~s}$ at room temperature. The two drying techniques used were: drying in air for $24 \mathrm{~h}$, and drying in oven at 50 ${ }^{\circ} \mathrm{C}$ for $60 \mathrm{~min}$. The two types of filter papers used were: Smith filter paper AO336 with 15-20 $\mu \mathrm{m}$ pore size (Smith Scientific Ltd., UK) and Whatman filter paper with $11 \mu \mathrm{m}$ pore size (GE Healthcare UK Ltd., UK).

\section{Centrifugation approach}

The $\mathrm{CaCO}_{3} \mu$-spheres were fabricated by precipitation reaction between $\mathrm{CaCl}_{2}$ and $\mathrm{Na}_{2} \mathrm{CO}_{3}$ solutions as reported by Volodkin et al. [16, 17] with slight alteration. Briefly, $20 \mathrm{~mL}$ of $0.33 \mathrm{M}$ solutions of $\mathrm{CaCl}_{2}$ and $\mathrm{Na}_{2} \mathrm{CO}_{3}$ were mixed under vigorous stirring at $900 \mathrm{rpm}$ for $30 \mathrm{~s}$ at room temperature. After the stirrer was stopped, the reaction mixture was left without stirring for $10 \mathrm{~min}$. Subsequently, centrifugation washing steps with distilled water for four times were conducted in order to eliminate the unreacted species [18]. The $\mathrm{CaCO}_{3} \mu$-spheres were then washed by centrifugation with acetone twice. Finally the $\mu$-spheres were dried.

Two different mixing procedures, four different stirring speeds, two different drying techniques, two different centrifugation times and two different quantities of washing agents were carried out in order to understand the effect of these experimental factors on the morphology and size distribution of $\mathrm{CaCO}_{3} \mu$-spheres. In the case of first, second, and third experimental factors, parameters similar to the membrane filtration were used. The two centrifugation times (at $1000 \mathrm{rpm}$ ) used were: $1 \mathrm{~min}$ and $5 \mathrm{~min}$. The two quantities of washing agents (distilled water and acetone) used were: $25 \mathrm{~mL}$ and $40 \mathrm{~mL}$.

\section{Characterization of $\mathrm{CaCO}_{3} \mu$-spheres}

The shape and size measurements of the $\mathrm{CaCO}_{3} \mu$-spheres were investigated using a compound microscope (Nikon ECLIPSE E100) at 4x, 10x, 40x, and 100x magnification. Powder samples of $\mathrm{CaCO}_{3} \mu$-spheres were used for the compound microscopy experiments. The compound microscope was equipped with Dino-eye (Microscope EyePiece Camera) to take the images and DinoCapture 2.0 software to measure the diameters of $\mathrm{CaCO}_{3} \mu$-spheres. The fine surface morphological details of the $\mathrm{CaCO}_{3} \mu$-spheres were observed using a scanning electron microscope (SEM) (JSM-6360 LA JEOL, US).

\section{Data analysis}

The statistical analysis to determine the mean and standard deviation of the diameters of $\mathrm{CaCO}_{3} \mu$-spheres was done using SPSS software. Histograms overlaid with a normal distribution curve showing the size distribution of $\mathrm{CaCO}_{3}$ $\mu$-spheres was also done using the same software.

\section{Results and Discussion}

For most applications, narrow size distribution and uniform shape of $\mathrm{CaCO}_{3} \mu$-spheres are highly desirable characteristics. In order to achieve the desired $\mu$-sphere characteristics, the experimental factors related with the preparation of $\mu$-spheres using distilled water were studied. For the membrane filtration approach, the experimental factors tested included mixing procedure of solutions, stirring speeds, drying techniques, and types of filter paper used. For the centrifugation approach, the experimental factors tested included mixing procedure of solutions, stirring speeds, centrifugation times, drying techniques, and quantity of washing agents used. The results from the different experimental factors tested (under membrane filtration and centrifugation approaches) in order to understand their influence on the formation of $\mathrm{CaCO}_{3} \mu$-spheres are presented and discussed in terms of shape and size distribution of the $\mu$-spheres in the following sections.

\section{Effect of mixing procedure of solutions}

Figures 1a and 1c show the $\mathrm{CaCO}_{3} \mu$-spheres obtained from the rapid addition mixing procedure of solutions that produced spherical shaped $\mu$-spheres. The average size of $\mu$-spheres was $5.93 \pm 0.72 \mu \mathrm{m}$ and $5.33 \pm 0.95 \mu \mathrm{m}$ for membrane filtration and centrifugation approaches, respectively. Compound microscopy results show that the $\mathrm{CaCO}_{3} \mu$-spheres formed clusters when using drop-by-drop addition mixing procedure of solutions (Figures 1b, 1d). The reaction mixture should be mixed rapidly (reactive precipitation) and then left undisturbed for certain time. The solutions were left undisturbed for around $10 \mathrm{~min}$ in order to allow the crystal nucleation and growth of $\mathrm{CaCO}_{3}$. The histograms in Figure 2 show that both approaches produced narrow size distributions of $\mathrm{CaCO}_{3} \mu$-spheres; with a positively skewed distribution for the membrane filtration approach. 

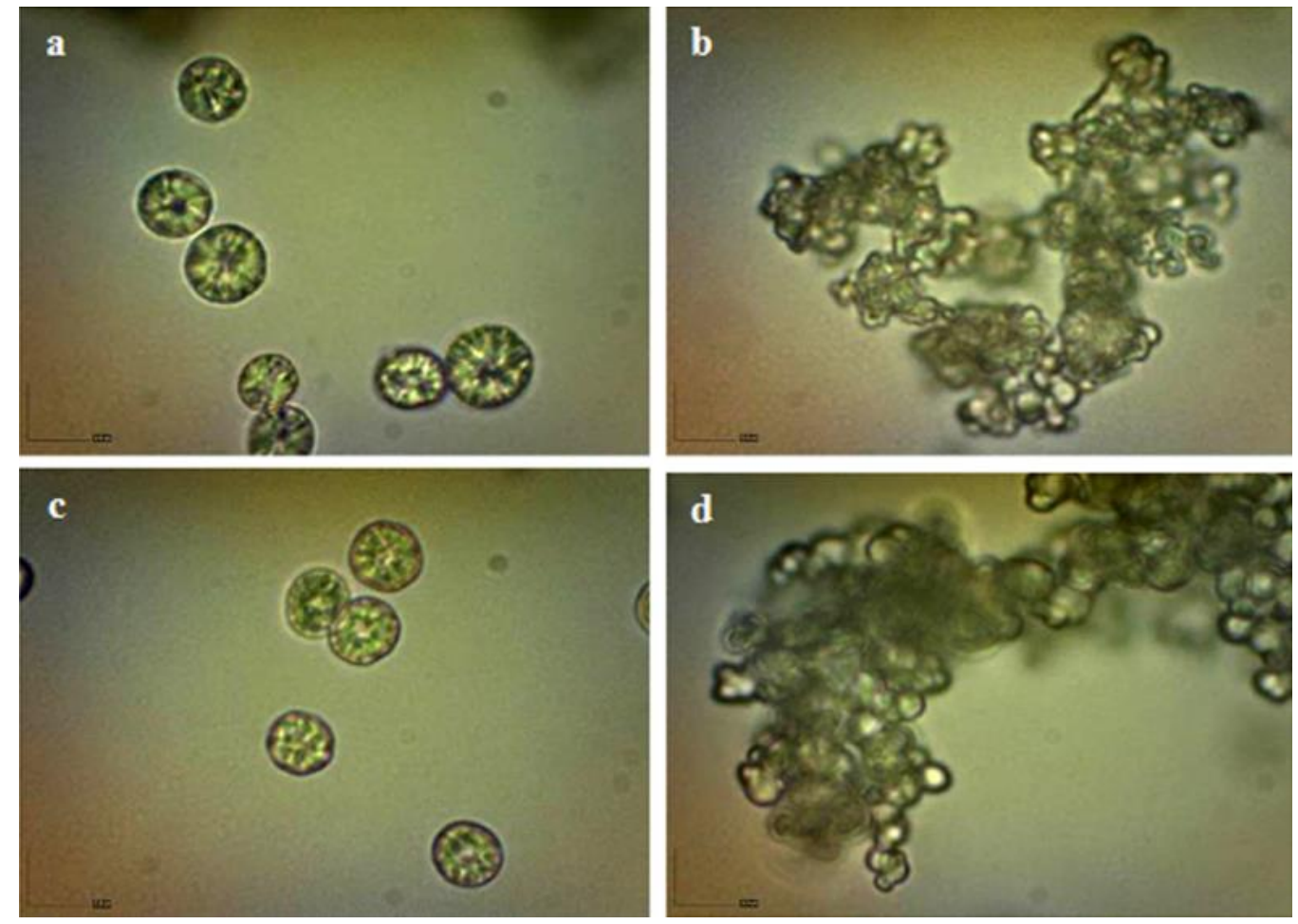

Figure 1. Microscope images of $\mathrm{CaCO}_{3} \mu$-spheres fabricated using different mixing procedures of solutions (a, c) $\mathrm{Na}_{2} \mathrm{CO}_{3}$ was added directly to $\mathrm{CaCl}_{2}$ and (b, d) $\mathrm{Na}_{2} \mathrm{CO}_{3}$ was added drop-by-drop to $\mathrm{CaCl}_{2}$. Membrane filtration approach $(\mathrm{a}, \mathrm{b})$ and centrifugation approach $(\mathrm{c}, \mathrm{d})(100 \mathrm{x}$ magnification, scale bars indicate $5 \mu \mathrm{m})$
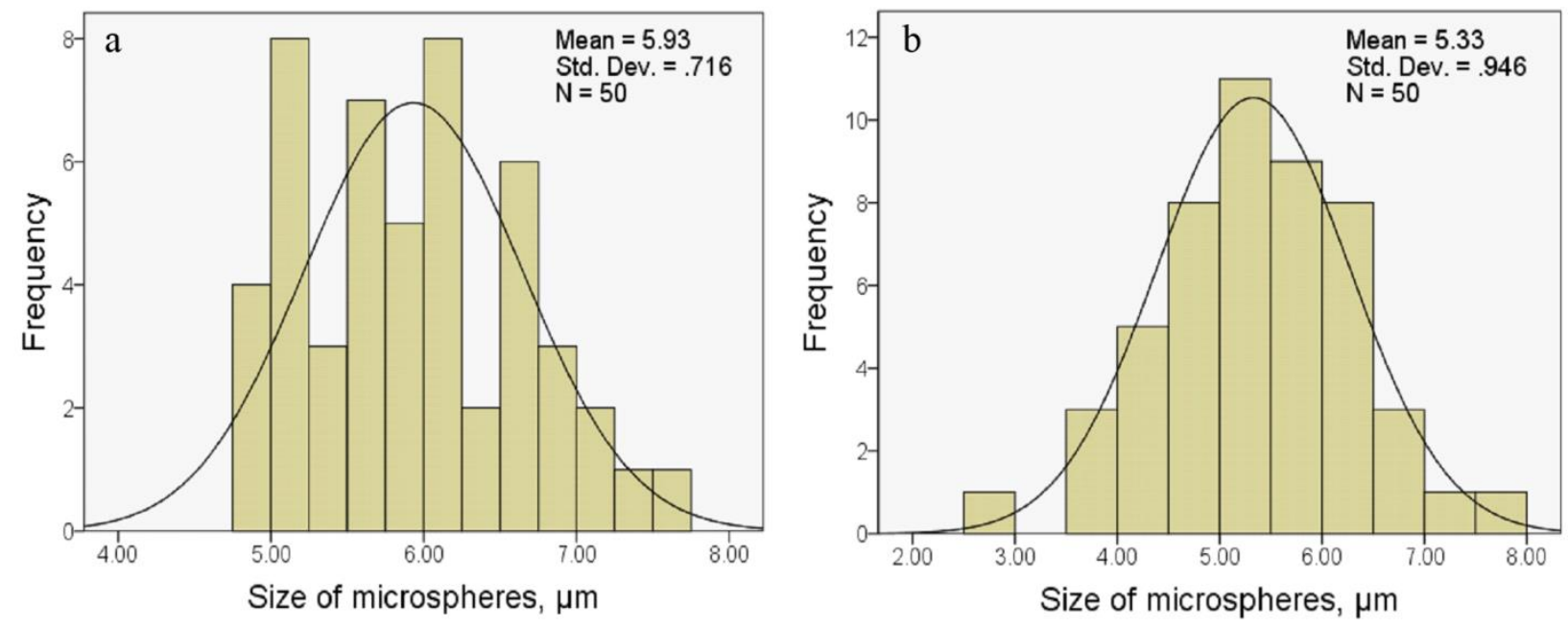

Figure 2. Histograms showing size distribution for $\mathrm{CaCO}_{3} \mu$-spheres fabricated using rapid addition mixing procedure of solutions (a) membrane filtration approach and (b) centrifugation approach 


\section{Effect of stirring speed}

Compound microscopy images show that the $\mathrm{CaCO}_{3} \mu$-spheres obtained using stirring speeds of 300,600 , and 900 rpm have a mixture of calcite and spherical shapes (Figures 3a, 3b, 3c, 3e, 3f, and 3g). As shown by representative images, it was observed that non-uniform sizes and shapes of $\mathrm{CaCO}_{3} \mu$-spheres were obtained at lower stirring speeds. Uniform shaped $\mathrm{CaCO}_{3} \mu$-spheres were achieved at a stirring speed of $1200 \mathrm{rpm}$ (Figures $3 \mathrm{~d}$, 3h), with the average sphere diameters of $4.98 \pm 0.57 \mu \mathrm{m}$ and $7.27 \pm 0.78 \mu \mathrm{m}$ for membrane filtration and centrifugation approaches, respectively. Histograms in Figure 4 show that both approaches produced narrow size distribution of $\mathrm{CaCO}_{3} \mu$-spheres; with a negatively skewed distribution for the centrifugation approach. The results indicate that stirring speed has an effect on the shape and size of the $\mu$-spheres and that higher stirring speed yields better size distribution and spherical $\mathrm{CaCO}_{3} \mu$-spheres, similar to previously reported work [14].
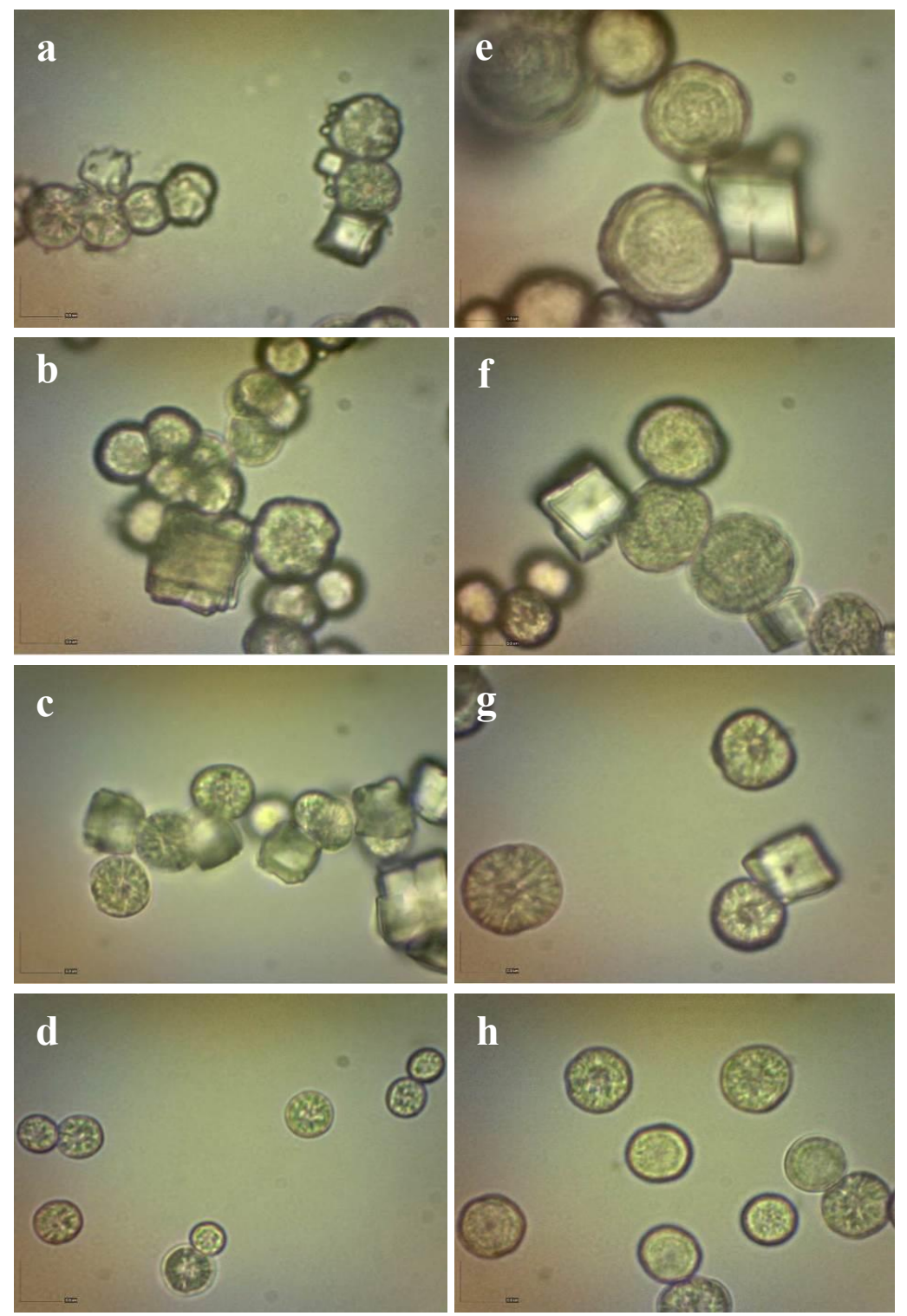

Figure 3. Microscope images of $\mathrm{CaCO}_{3} \mu$-spheres fabricated using different stirring speeds (a, e) $300 \mathrm{rpm}$, (b, f) $600 \mathrm{rpm},(\mathrm{c}, \mathrm{g}) 900 \mathrm{rpm}$ and (d, h) $1200 \mathrm{rpm}$. Membrane filtration approach (a to d) and centrifugation approach (e to h) (100x magnification, scale bars indicate $5 \mu \mathrm{m})$ 

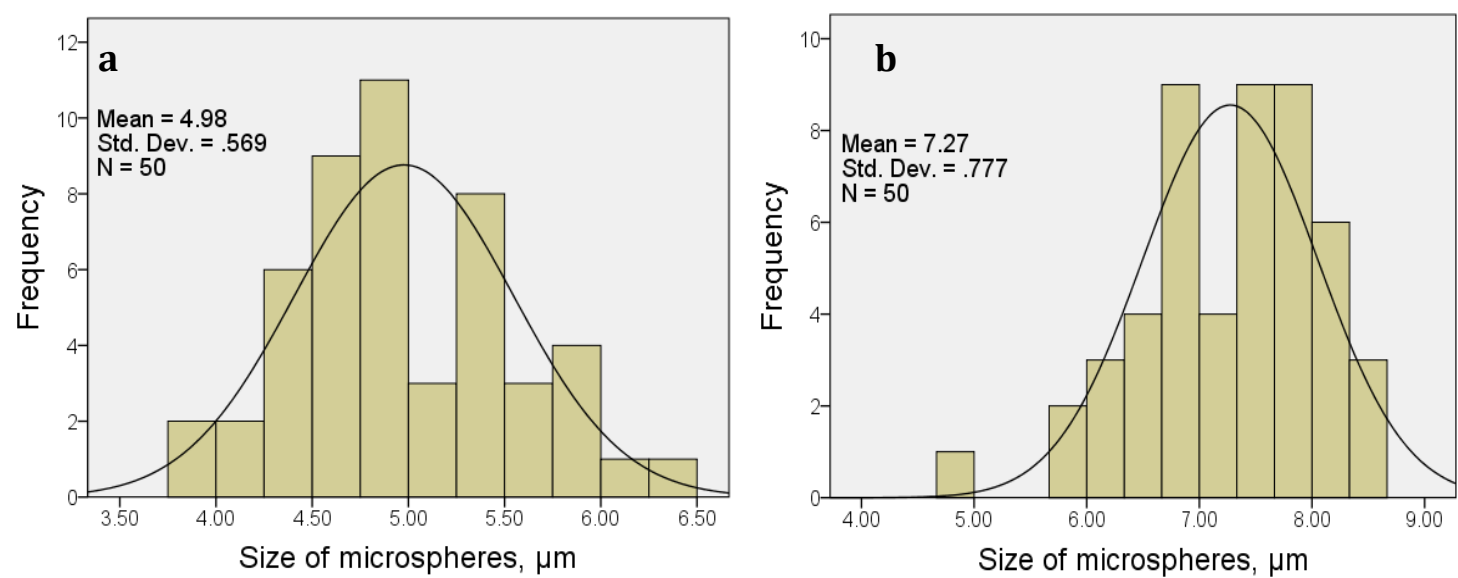

Figure 4. Histograms showing size distribution for $\mathrm{CaCO}_{3} \mu$-spheres fabricated using a stirring speed of $1200 \mathrm{rpm}$ (a) membrane filtration approach and (b) centrifugation approach

\section{Effect of drying technique}

The purpose of drying the $\mathrm{CaCO}_{3} \mu$-spheres was to remove physically adsorbed water or acetone from the $\mu$ spheres. Figures $5 \mathrm{a}$ and $5 \mathrm{c}$ show that spherical shaped $\mathrm{CaCO}_{3} \mu$-spheres were obtained when dried in air. $\mathrm{CaCO}_{3} \mu$ spheres obtained by drying in oven at $50{ }^{\circ} \mathrm{C}$ had spherical and calcite shapes (Figures $5 \mathrm{~b}, 5 \mathrm{~d}$ ). The average size of $\mu$-spheres was $6.64 \pm 1.64 \mu \mathrm{m}$ and $5.33 \pm 0.95 \mu \mathrm{m}$ for membrane filtration and centrifugation approaches, respectively. Histograms in Figure 6 show that centrifugation approach produced narrow size distribution of $\mathrm{CaCO}_{3}$ $\mu$-spheres, whereas the membrane filtration approach has a bimodal distribution. The drying technique also influenced the final quantity of $\mathrm{CaCO}_{3} \mu$-spheres. It was observed that the $\mathrm{CaCO}_{3} \mu$-spheres dried in air were heavier than those dried in oven. With the membrane filtration approach, the average weight of $\mathrm{CaCO}_{3} \mu$-spheres obtained by drying in air was $0.95 \pm 0.04 \mathrm{~g}$ and by drying in oven was $0.58 \pm 0.13 \mathrm{~g}$. Similar results were obtained with the centrifugation approach, where the average weight of $\mathrm{CaCO}_{3} \mu$-spheres by drying in air was $0.50 \pm 0.19 \mathrm{~g}$ and by drying in oven was $0.43 \pm 0.15 \mathrm{~g}$. Overall, the results indicate that membrane filtration approach yields more quantity of $\mathrm{CaCO}_{3} \mu$-spheres compared to the centrifugation approach, and drying at room temperature provides spherical shaped $\mathrm{CaCO}_{3} \mu$-spheres.
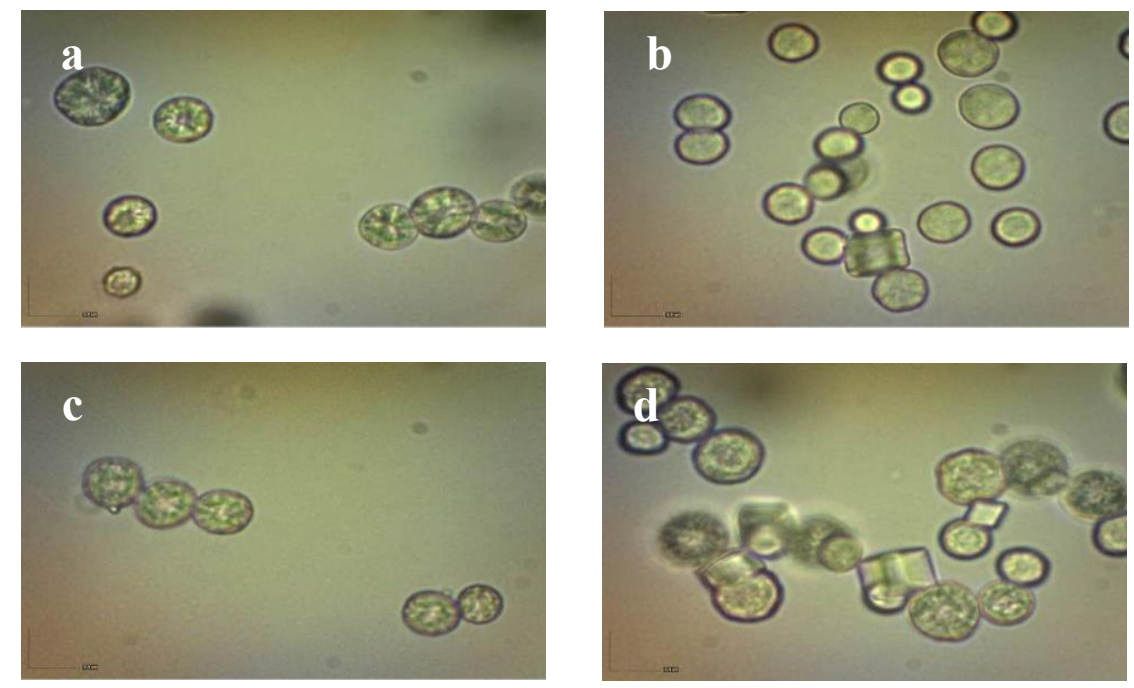

Figure 5. Microscope images of $\mathrm{CaCO}_{3} \mu$-spheres fabricated using different drying techniques (a, c) dried in air and $(\mathrm{b}, \mathrm{d})$ dried in oven at $50^{\circ} \mathrm{C}$. Membrane filtration approach $(\mathrm{a}, \mathrm{b})$ and centrifugation approach $(\mathrm{c}, \mathrm{d})(100 \mathrm{x}$ magnification, scale bars indicate $5 \mu \mathrm{m}$ ) 

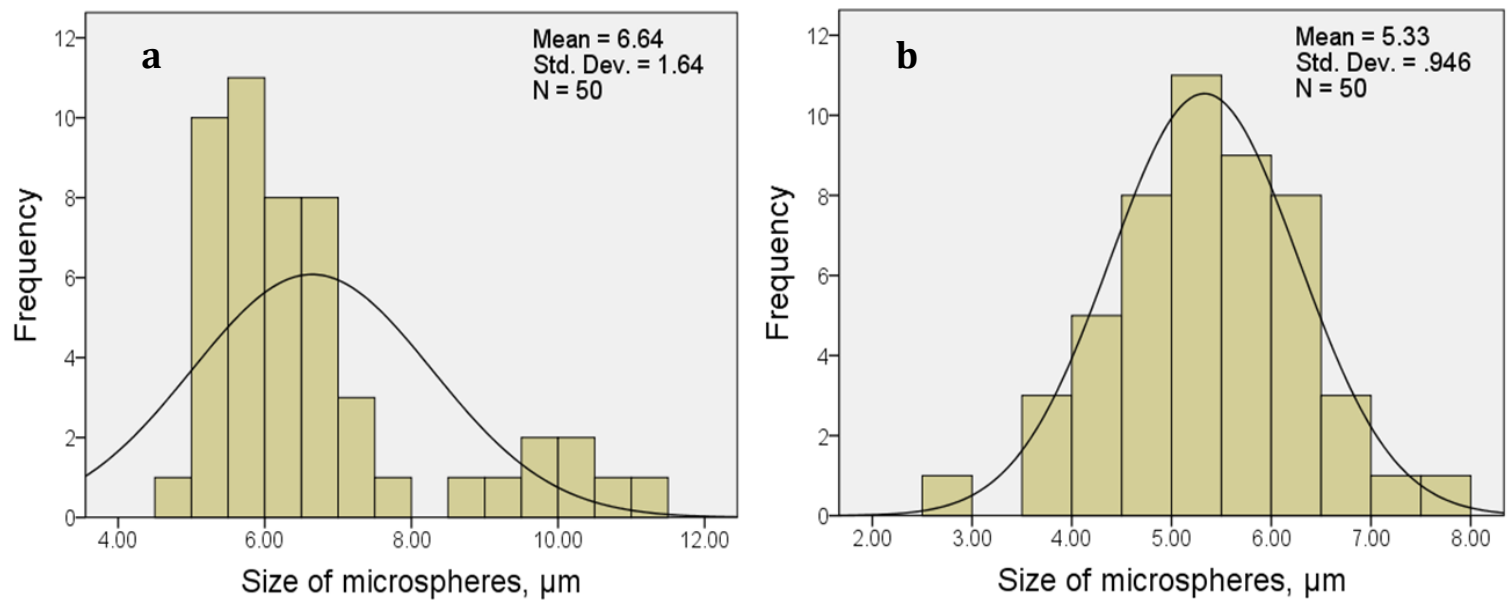

Figure 6. Histograms showing size distribution for $\mathrm{CaCO}_{3} \mu$-spheres fabricated by drying in air (a) Membrane filtration approach and (b) centrifugation approach

\section{Effect of type of filter paper}

Figure 7 shows the effect of using different brands of filter paper that have different pore sizes. Compound microscope images show that $\mathrm{CaCO}_{3} \mu$-spheres obtained by using Smith filter paper (with $15-20 \mu \mathrm{m}$ pore size) had spherical shape and better size distribution (Figure 7a).
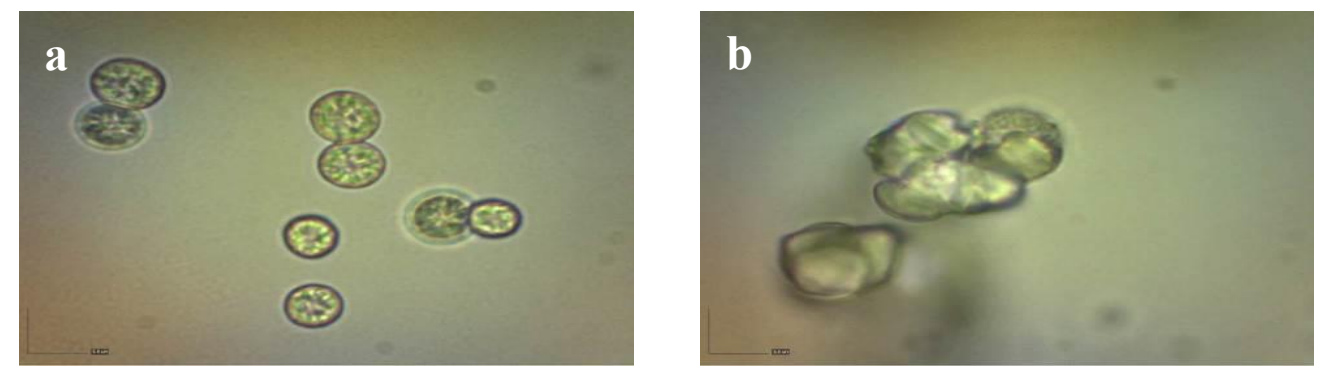

Figure 7. Microscope images of $\mathrm{CaCO}_{3} \mu$-spheres fabricated using different types of filter paper in membrane filtration approach (a) Smith filter paper and (b) Whatman filter paper (100x magnification, scale bars indicate $5 \mu \mathrm{m}$ )

Images of $\mathrm{CaCO}_{3} \mu$-spheres obtained using Whatman filter paper had irregular particles (Figure 7b). The average size of the $\mu$-spheres was $4.98 \pm 0.57 \mu \mathrm{m}$ by using smith filter paper. Histogram in Figure 8 shows that using membrane filtration system equipped with the smith filter paper yielded a narrow distribution of $\mathrm{CaCO}_{3} \mu$-spheres. The results depict that the smith filter paper used here is more suitable to produce $\mathrm{CaCO}_{3} \mu$-spheres.

\section{Effect of centrifugation time}

For centrifugation washing step at $1000 \mathrm{rpm}$ for $1 \mathrm{~min}$, uniform spherical $\mathrm{CaCO}_{3} \mu$-spheres were obtained (Figure 9a); at $1000 \mathrm{rpm}$ for $5 \mathrm{~min}$, agglomeration (clustering) of the $\mathrm{CaCO}_{3} \mu$-spheres was observed (Figure 9b). The average size of the $\mu$-spheres was $5.14 \pm 0.68 \mu \mathrm{m}$ for centrifugation time of $1 \mathrm{~min}$. Histogram in Figure 10 shows a narrow distribution of $\mathrm{CaCO}_{3} \mu$-spheres obtained for centrifugation time of $1 \mathrm{~min}$. The results indicate that a shorter centrifugation time results in spherical shapes and narrow size distribution of $\mathrm{CaCO}_{3} \mu$-spheres. 


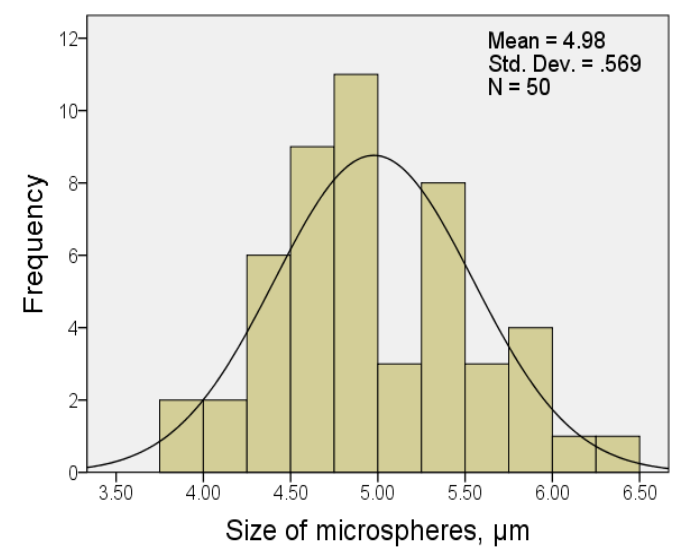

Figure 8. Histogram showing size distribution for $\mathrm{CaCO}_{3} \mu$-spheres fabricated using Smith filter paper
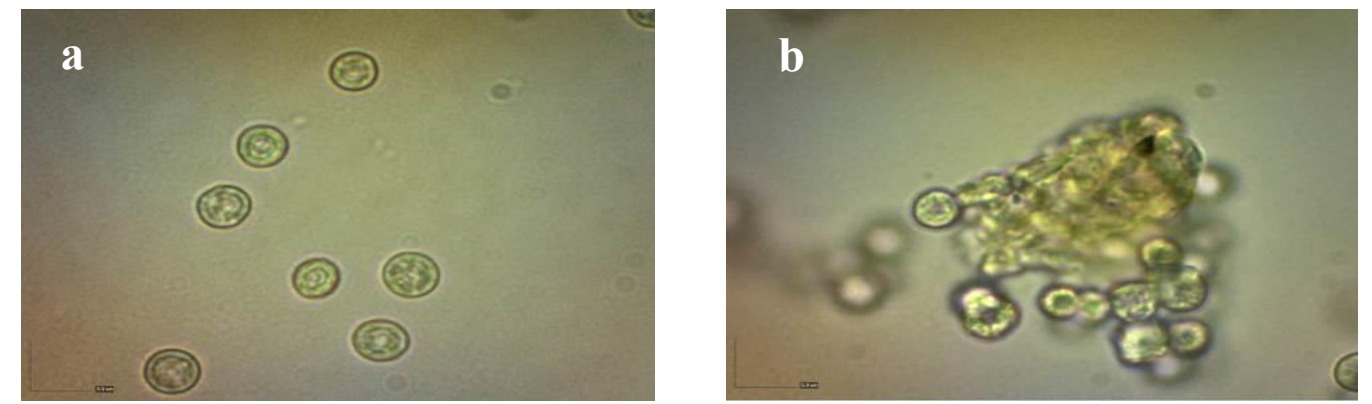

Figure 9. Microscope images of $\mathrm{CaCO}_{3} \mu$-spheres fabricated using different times (a) 1 min, (b) 5 min centrifugation at $1000 \mathrm{rpm}(100 \mathrm{x}$ magnification, scale bars indicate $5 \mu \mathrm{m})$

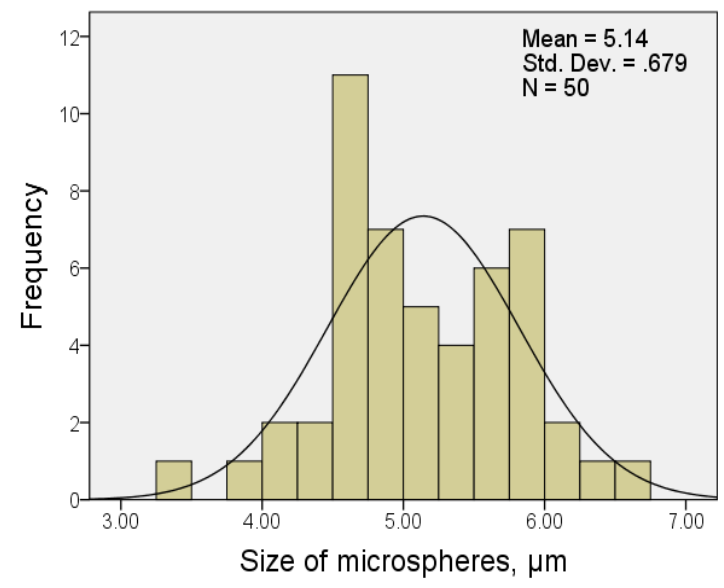

Figure 10. Histogram showing size distribution for $\mathrm{CaCO}_{3} \mu$-spheres fabricated by centrifugation at $1000 \mathrm{rpm}$ for $1 \mathrm{~min}$ 


\section{Effect of quantity of washing agents}

Before drying, the $\mu$-spheres were washed with distilled water and acetone for several times in order to eliminate the unreacted species. Figure 11a shows that spherical $\mu$-spheres with average diameter of $4 \pm 0.52 \mu \mathrm{m}$ were obtained by using $25 \mathrm{~mL}$ of washing agents. Figure $11 \mathrm{~b}$ shows that cauliflower-shaped $\mathrm{CaCO}_{3} \mu$-spheres [19] were obtained by using $40 \mathrm{~mL}$ of washing agents. The results might be a consequence of the capacity of the centrifuge tube used; $25 \mathrm{~mL}$ of washing agents appeared to be suitable with $50 \mathrm{~mL}$ centrifuge tubes used in this study. Histogram in Figure 12 shows narrow distribution of $\mathrm{CaCO}_{3} \mu$-spheres obtained using $25 \mathrm{~mL}$ of washing agents.
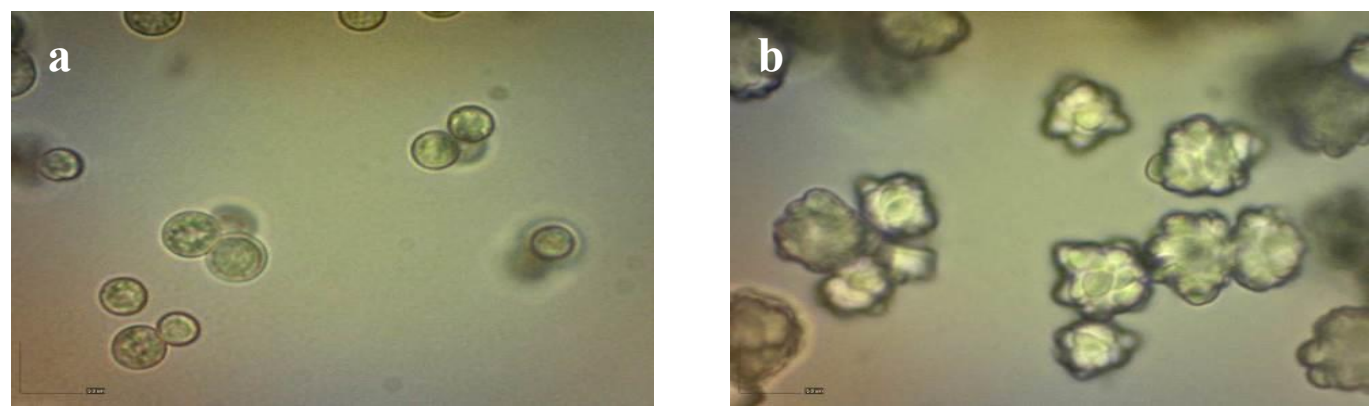

Figure 11. Microscope images of $\mathrm{CaCO}_{3} \mu$-spheres fabricated using different quantity of centrifugation washing agents (a) $25 \mathrm{~mL}$ and (b) $40 \mathrm{~mL}$ of distilled water and acetone (100x magnification, scale bars indicate $5 \mu \mathrm{m})$

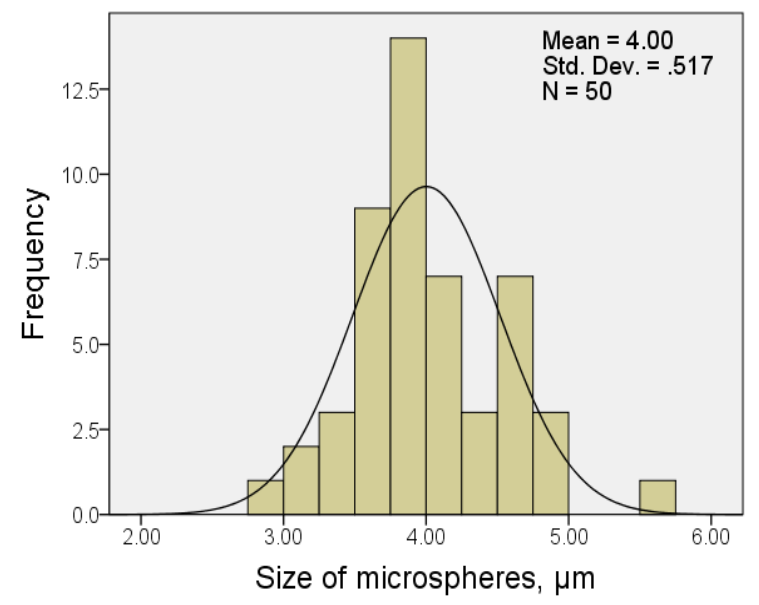

Figure 12. Histogram showing size distribution for $\mathrm{CaCO}_{3} \mu$-spheres fabricated using $25 \mathrm{~mL}$ of centrifugation washing agents

Table 1 summarizes the results obtained for the $\mathrm{CaCO}_{3} \mu$-spheres from all the experiments conducted to evaluate the influence of different experimental factors. For each fabrication approach, the experimental factors that yielded the best results were used to fabricate a new set of $\mathrm{CaCO}_{3} \mu$-spheres. For membrane filtration approach (microscopy images shown in Figure 13a) the fabrication conditions used were direct mixing, stirring speed of $1200 \mathrm{rpm}$, drying in air, and Smith filter paper, whereas for centrifugation approach (microscopy images shown in Figure 13b) the fabrication conditions used were direct mixing, stirring speed of $1200 \mathrm{rpm}$, drying in air, centrifugation time of 1 min, and $25 \mathrm{~mL}$ of centrifugation washing agent. The average size of $\mu$-spheres was $5.14 \pm 0.68 \mu \mathrm{m}$ and $4.81 \pm 1.51$ $\mu \mathrm{m}$ for centrifugation and membrane filtration approaches, respectively. Based on the final weight of $\mathrm{CaCO}_{3} \mu$ - 
spheres, membrane filtration approach produced more quantity (average weight of $0.77 \pm 0.16 \mathrm{~g}$ ) than centrifugation approach (average weight of $0.59 \pm 0.07 \mathrm{~g}$ ). Histograms in Figure 14 show that the centrifugation approach yields better size distribution compared to the membrane filtration approach which has a bimodal distribution. SEM micrographs in Figure 15 show the spherical shaped $\mathrm{CaCO}_{3} \mu$-spheres. The higher magnification micrographs clearly show the typical surface morphology of $\mathrm{CaCO}_{3} \mu$-spheres.

Table 1. Summary of influence of experimental factors on $\mathrm{CaCO}_{3}$ microsphere shape and size

\begin{tabular}{|c|c|c|c|c|c|}
\hline Factor & & Figure & Weight (g) & Structure/Shape & Particle size $(\mu \mathrm{m})$ \\
\hline \multirow{4}{*}{$\begin{array}{l}\text { Mixing procedure } \\
\text { of solutions }\end{array}$} & \multirow{2}{*}{$\begin{array}{l}\text { Rapidly } \\
\text { (directly) }\end{array}$} & $1 \mathrm{a}$ & 0.94 & Spherical $^{\mathrm{a}}$ & $5.93 \pm 0.72$ \\
\hline & & $1 \mathrm{c}$ & 0.72 & Spherical $^{\mathrm{a}}$ & $5.33 \pm 0.95$ \\
\hline & \multirow{2}{*}{$\begin{array}{l}\text { Drop-by- } \\
\text { Drop }\end{array}$} & $1 b$ & 1.06 & Agglomeration & $-{ }^{b}$ \\
\hline & & $1 d$ & 0.25 & Agglomeration & $-{ }^{b}$ \\
\hline \multirow{8}{*}{$\begin{array}{l}\text { Stirring speeds } \\
(\mathrm{rpm})\end{array}$} & \multirow{2}{*}{300} & $3 a$ & 0.71 & Calcite, Cluster & $-\mathrm{b}$ \\
\hline & & $3 e$ & 0.59 & Calcite, Cluster & $-{ }^{\mathrm{b}}$ \\
\hline & \multirow{2}{*}{600} & $3 b$ & 0.75 & Calcite, Cluster & $-{ }_{-b}^{b}$ \\
\hline & & $3 f$ & 0.60 & Calcite, Cluster & $-{ }^{\mathrm{b}}$ \\
\hline & \multirow{2}{*}{900} & $3 \mathrm{c}$ & 0.70 & Calcite, Cluster & $-{ }^{b}$ \\
\hline & & $3 g$ & 0.62 & Calcite, Cluster & $-{ }^{\mathrm{b}}$ \\
\hline & \multirow{2}{*}{1200} & $3 d$ & 0.80 & Spherical $^{\mathrm{a}}$ & $4.98 \pm 0.57$ \\
\hline & & $3 \mathrm{~h}$ & 0.63 & Spherical $^{\mathrm{a}}$ & $7.27 \pm 0.78$ \\
\hline \multirow[t]{4}{*}{ Drying technique } & \multirow{2}{*}{ Air } & $5 \mathrm{a}$ & 0.95 & Spherical $^{\mathrm{a}}$ & $6.64 \pm 1.64$ \\
\hline & & $5 c$ & 0.50 & Spherical $^{\mathrm{a}}$ & $5.33 \pm 0.95$ \\
\hline & \multirow{2}{*}{$\begin{array}{l}\text { Oven } \\
\left(50^{\circ} \mathrm{C}\right)\end{array}$} & $5 b$ & 0.58 & Spherical $^{\mathrm{a}}$, Calcite & $-{ }^{b}$ \\
\hline & & $5 \mathrm{~d}$ & 0.43 & Spherical $^{\mathrm{a}}$, Calcite, Cluster & $-{ }^{b}$ \\
\hline \multirow{2}{*}{$\begin{array}{l}\text { Type of filter } \\
\text { Paper }\end{array}$} & \multirow{2}{*}{\multicolumn{2}{|c|}{$\begin{array}{l}\text { Smith } \\
\text { Whatman }\end{array}$}} & 0.80 & Spherical $^{\mathrm{a}}$ & $4.98 \pm 0.57$ \\
\hline & & & 0.90 & Irregular particles & $-\mathrm{b}$ \\
\hline \multirow{2}{*}{$\begin{array}{l}\text { Centrifugation } \\
\text { time }\end{array}$} & \multirow{2}{*}{\multicolumn{2}{|c|}{$\begin{array}{l}1000 \mathrm{rpm}, 1 \mathrm{~min} . \\
1000 \mathrm{rpm}, 5 \mathrm{~min} .\end{array}$}} & 0.56 & Spherical $^{\mathrm{a}}$ & $5.14 \pm 0.68$ \\
\hline & & & 0.66 & Spherical $^{\mathrm{a}}$, Agglomeration & $-\mathrm{b}$ \\
\hline \multirow{2}{*}{$\begin{array}{l}\text { Centrifugation } \\
\text { washing agents }\end{array}$} & \multirow{2}{*}{\multicolumn{2}{|c|}{$\begin{array}{l}25 \mathrm{~mL} \\
40 \mathrm{~mL}\end{array}$}} & 0.41 & Spherical $^{\mathrm{a}}$ & $4 \pm 0.52$ \\
\hline & & & 0.37 & Cauliflower-shaped & $-{ }^{b}$ \\
\hline
\end{tabular}

${ }^{\mathrm{a}}$ Nearly spherical

$-{ }^{\mathrm{b}}$ Clustered or agglomeration structure (data not analysed) 

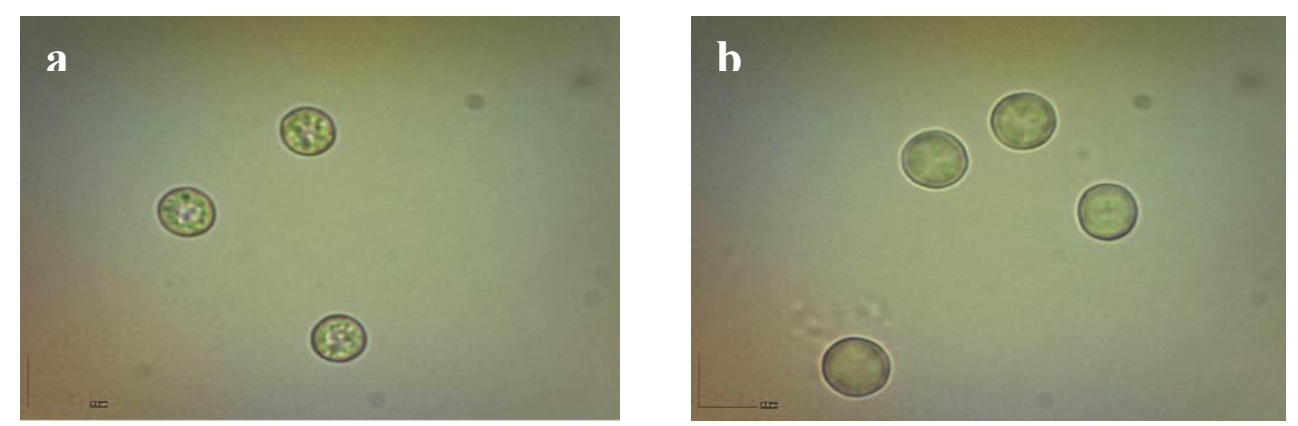

Figure 13. Microscope images of $\mathrm{CaCO}_{3} \mu$-spheres fabricated using (a) membrane filtration approach and (b) centrifugation approach (100x magnification, scale bars indicate $5 \mu \mathrm{m}$ )
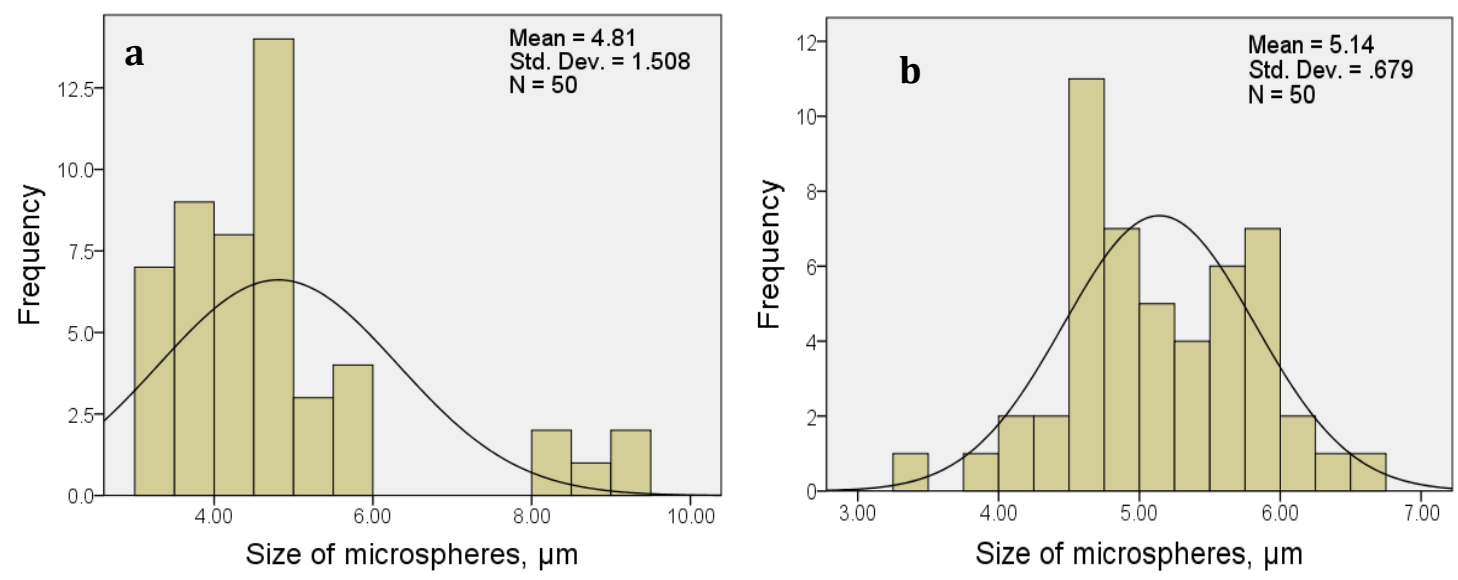

Figure 14. Histograms showing size distribution for $\mathrm{CaCO}_{3} \mu$-spheres fabricated using (a) Membrane filtration approach and (b) centrifugation approach
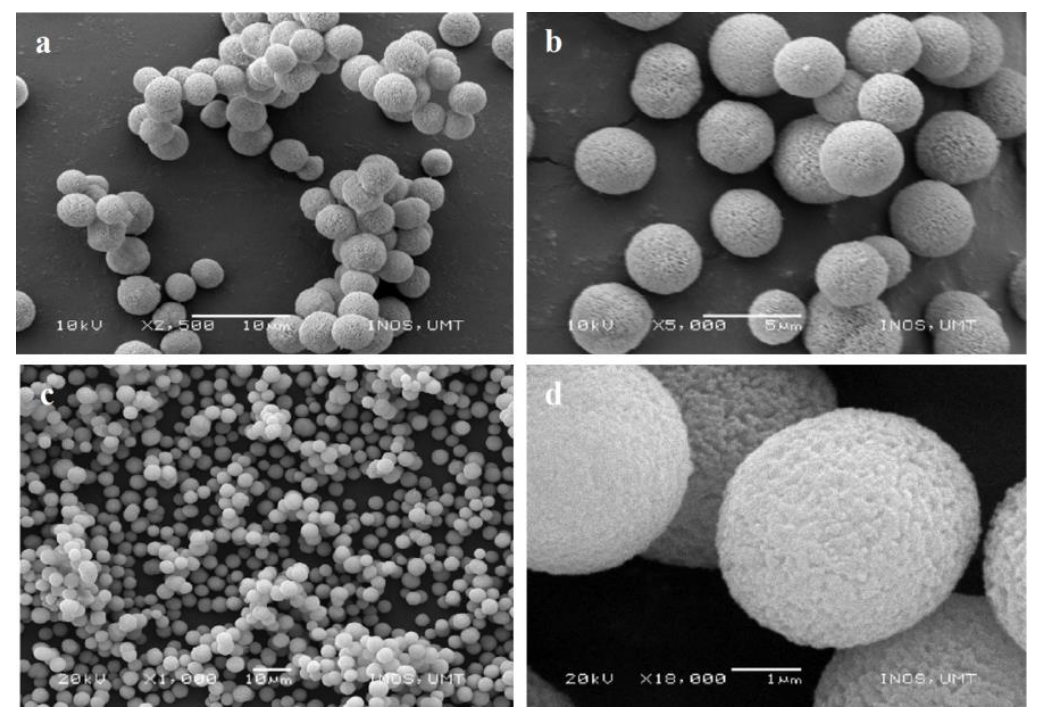

Figure 15. SEM images of $\mathrm{CaCO}_{3} \mu$-spheres (a, b) taken using $10 \mathrm{kV}$, and (c, d) taken using $20 \mathrm{kV}$ 
Overall, the results indicate that the centrifugation approach can yield better $\mathrm{CaCO}_{3} \mu$-spheres as compared to the membrane filtration approach in terms of uniform spherical shape and narrow size distribution of $\mu$-spheres. These two are the desired characteristics for the $\mathrm{CaCO}_{3} \mu$-spheres that would be used as templates for fabricating nanoengineered microcapsules.

\section{Conclusion}

Fabrication of $\mathrm{CaCO}_{3} \mu$-spheres using precipitation reaction between $\mathrm{CaCl}_{2}$ and $\mathrm{Na}_{2} \mathrm{CO}_{3}$ solutions was carried out using membrane filtration and centrifugation approaches by varying different experimental factors that have important roles in the formation of $\mathrm{CaCO}_{3} \mu$-spheres; with distilled water used throughout the experiments. Better size distribution of $\mathrm{CaCO}_{3} \mu$-spheres was obtained through direct mixing procedure of solutions, $1200 \mathrm{rpm}$ of stirring speed, and drying in air for both the approaches. Also, better size distribution of $\mathrm{CaCO}_{3} \mu$-spheres was obtained through using Smith filter paper in the case of the membrane filtration approach and at $1000 \mathrm{rpm}$ for $1 \mathrm{~min}$ centrifugation time, using $25 \mathrm{~mL}$ of washing agents in the case of the centrifugation approach. Overall, our results indicate that the centrifugation approach can yield better $\mathrm{CaCO}_{3} \mu$-spheres as compared to the membrane filtration approach in terms of uniform spherical shape and narrow size distribution of $\mu$-spheres. The knowledge from this study will be used to prepare $\mathrm{CaCO}_{3} \mu$-spheres that will act as templates for fabricating nano-engineered microcapsules.

\section{Acknowledgement}

This work was supported by Ministry of Higher Education (MOHE), Malaysia under the Fundamental Research Grant Scheme (FRGS), Grant no.: FRGS/1/2014/TK04/UNISZA/02/1.

\section{References}

1. Petrov, A. I., Volodkin, D. V. and Sukhorukov, G. B. (2005). Protein-calcium carbonate coprecipitation: A tool for protein encapsulation. Biotechnology Progress, 21: 918 - 925.

2. De Temmerman, M.-L., Demeester, J., De Vos, F. and De Smedt, S. C. (2011). Encapsulation performance of layer-by-layer microcapsules for proteins. Biomacromolecules, 12: 1283 - 1289.

3. Chapel, J.-P. and Berret, J.-F. (2012). Versatile electrostatic assembly of nanoparticles and polyelectrolytes: Coating, clustering and layer-by-layer processes. Current Opinion in Colloid and Interface Science, 17: 97 105.

4. Shimpi, N. and Mishra, S. (2010). Synthesis of nanoparticles and its effect on properties of elastomeric nanocomposites. Journal of Nanoparticle Research, 12: 2093 - 2099.

5. Mishra, S. and Shimpi, N. (2005). Comparison of nano $\mathrm{CaCO}_{3}$ and flyash filled with styrene butadiene rubber on mechanical and thermal properties. Journal of Scientific \& Industrial Research, 64: 744 - 751.

6. Gumfekar, S., Kunte, K., Ramjee, L., Kate, K. and Sonawane, S. (2011). Synthesis of CaCO 3-P (MMA-BA) nanocomposite and its application in water based alkyd emulsion coating. Progress in Organic Coatings, 72: $632-637$.

7. Kirboga, S. and Oner, M. (2013). Effect of the experimental parameters on calcium carbonate precipitation. Chemical Engineering Transactions, 32: 2119 - 2124.

8. Tai, C. Y. and Chen, C. (2008). Particle morphology, habit, and size control of $\mathrm{CaCO}_{3}$ using reverse microemulsion technique. Chemical Engineering Science, 63: 3632 - 3642.

9. Hanafy, N. A. N., De Giorgi, M. L., Nobile, C., Rinaldi, R. and Leporatti, S. (2015). Control of colloidal $\mathrm{CaCO}_{3}$ suspension by using biodegradable polymers during fabrication. Beni-Suef University Journal of Basic and Applied Sciences, 4: $60-70$.

10. Kitamura, M., Konno, H., Yasui, A. and Masuoka, H. (2002). Controlling factors and mechanism of reactive crystallization of calcium carbonate polymorphs from calcium hydroxide suspensions. Journal of Crystal Growth, 236: $323-332$.

11. Koris, A. and Vatai, G. (2002). Dry degumming of vegetable oils by membrane filtration. Desalination, 148: $149-153$.

12. Majekodunmi, S. O. (2015). A review on centrifugation in the pharmaceutical industry. Annals of Biomedical Engineering, 5: $67-78$.

13. Trippa, G. and Jachuck, R. (2003). Process intensification: precipitation of calcium carbonate using narrow channel reactors. Chemical Engineering Research and Design, 81: 766 -772. 
14. Prabu, S. B., Karunamoorthy, L., Kathiresan, S. and Mohan, B. (2006). Influence of stirring speed and stirring time on distribution of particles in cast metal matrix composite. Journal of Materials Processing Technology, 171: $268-273$.

15. Kowalczyk, B., Lagzi, I. and Grzybowski, B. A. (2011). Nanoseparations: Strategies for size and/or shapeselective purification of nanoparticles. Current Opinion in Colloid and Interface Science, 16: 135 - 148.

16. Volodkin, D. V., Petrov, A. I., Prevot, M. and Sukhorukov, G. B. (2004). Matrix polyelectrolyte microcapsules: new system for macromolecule encapsulation. Langmuir, 20: 3398 - 3406.

17. Volodkin, D. V., Larionova, N. I. \& Sukhorukov, G. B. (2004). Protein encapsulation via porous $\mathrm{CaCO}_{3}$ microparticles templating. Biomacromolecules, 5: $1962-1972$.

18. Lee, S., Park, J.-H., Kwak, D. and Cho, K. (2010). Coral mineralization inspired $\mathrm{CaCO}_{3}$ deposition via $\mathrm{CO}_{2}$ sequestration from the atmosphere. Crystal Growth \& Design, 10: $851-855$.

19. Ouhenia, S., Chateigner, D., Belkhir, M., Guilmeau, E. \& Krauss, C. (2008). Synthesis of calcium carbonate polymorphs in the presence of polyacrylic acid. Journal of Crystal Growth, 310: 2832 -2841. 